\title{
Evaluation of on-farm tools for colostrum quality measurement
}

\author{
A. L. Bartier, M. C. Windeyer, and L. Doepel ${ }^{1}$ \\ Department of Production Animal Health, University of Calgary, Calgary, AB, Canada T2N 4N1
}

\begin{abstract}
The objectives of this study were to determine the immunoglobulin G (IgG) content of colostrum on Alberta dairy farms and to determine which on-farm tool, the colostrometer or the Brix refractometer, was more highly correlated with IgG content as determined by radial immunodiffusion (RID). Colostrum samples (n $=569$ ) were collected between February and July 2012 from 13 commercial dairy farms in central Alberta, with herds ranging in size from 60 to 300 lactating cows. Immunoglobulin $\mathrm{G}$ content was determined directly by RID and indirectly by a colostrometer (specific gravity) and Brix refractometer (total solids). The Spearman correlation was used for the colostrometer and Brix refractometer data. According to RID analysis, 29.1\% of the colostrum samples contained $<50 \mathrm{mg} / \mathrm{mL} \mathrm{IgG}$. Concentrations ranged from 8.3 to $128.6 \mathrm{mg} / \mathrm{mL} \mathrm{IgG}$, with a median of $65.1 \mathrm{mg} / \mathrm{mL}$. Third or greater parity cows had higher colostral IgG content $(69.5 \pm 1.98 \mathrm{mg} /$ $\mathrm{mL})$ than second parity $(59.80 \pm 2.06 \mathrm{mg} / \mathrm{mL})$ or first parity $(62.2 \pm 1.73 \mathrm{mg} / \mathrm{mL})$ cows. The colostrometer data were more highly correlated with RID results $(\mathrm{r}=$ 0.77) than were the Brix refractometer data $(\mathrm{r}=0.64)$. Specificity and sensitivity were determined for the colostrometer and Brix refractometer compared with a cut-point of $50 \mathrm{mg} / \mathrm{mL}$ IgG as determined by RID. The highest combined value for sensitivity and specificity occurred at $80 \mathrm{mg} / \mathrm{mL}$ for the colostrometer (84.1 and $77.0 \%$, respectively) and $23 \%$ Brix (65.7 and $82.8 \%$, respectively). This study indicates that although the colostrometer data are better correlated with true IgG values, the user-friendly Brix refractometer is a more specific tool to detect colostrum of adequate quality.
\end{abstract}

Key words: colostrum, radial immunodiffusion, colostrometer, Brix refractometer, immunoglobulin G

\section{INTRODUCTION}

Dairy calves are born without any acquired immunity because there is no transfer of immunoglobulin across the placenta from the dam to the fetus (Larson et al., 1980). This means that newborn calves must

Received May 27, 2014.

Accepted November 23, 2014.

${ }^{1}$ Corresponding author: ldoepel@ucalgary.ca acquire passive immunity through the consumption of colostral IgG (Baumrucker et al., 2010). Insufficient consumption of IgG results in failure of transfer of passive immunity (FTP), defined as serum IgG $<10 \mathrm{mg} /$ $\mathrm{mL}$ (Calloway et al., 2002). By far the greatest factor contributing to mortality of preweaned calves is FTP, associated with 39 to $50 \%$ of preweaned calf mortality (Margerison and Downey, 2005). Failure of transfer of passive immunity is widespread, with a prevalence of $19.2 \%$ on US farms (Beam et al., 2009) and $37.1 \%$ in Ontario, Canada (Trotz-Williams et al., 2008). The prevalence of FTP in dairy calves in Alberta, Canada, is currently unknown. Prevention of FTP is achieved by timely feeding of adequate quantities of colostrum that contains a minimum of $50 \mathrm{mg}$ of $\mathrm{IgG} / \mathrm{mL}$ as measured by radial immunodiffusion (RID; McGuirk and Collins, 2004; Godden, 2008; Beam et al., 2009). Colostral IgG concentrations vary considerably: Quigley et al. (2013) reported a range of 7.1 to $159 \mathrm{mg} / \mathrm{mL}$, with $16 \%$ of samples containing $<50 \mathrm{mg} / \mathrm{mL}$, and Morrill et al. (2012a) reported values ranging from $<1.8$ to 200.2 $\mathrm{mg} / \mathrm{mL}$, with $29.4 \%$ of the samples containing $<50 \mathrm{mg} /$ $\mathrm{mL}$. Due to the high prevalence of FTP and poor quality colostrum, dairy producers should measure colostral IgG before feeding it to calves or storing it for later use.

Measurement of colostrum quality on farm must be reliable, accurate, and easy to perform. Traditionally, a colostrometer has been recommended to determine on-farm quality (Fleenor and Stott, 1980). The specific gravity of colostrum, as measured by the colostrometer, has been shown to have a high correlation with IgG concentrations determined by RID $\left(\mathrm{R}^{2}=0.699\right.$; Fleenor and Stott, 1980). Unfortunately, the colostrometer has several drawbacks that may limit its adoption on farm: it is made of glass and therefore is fragile; it needs to be thoroughly cleaned before each use; and colostrum must be at $22^{\circ} \mathrm{C}$ to obtain a reliable measurement. It has recently been suggested that the Brix refractometer is a reliable tool for determining bovine colostrum IgG content, and that a value between 18 and $23 \%$ Brix is an appropriate cut-point for good quality colostrum (Chigerwe et al., 2008; Bielmann et al., 2010; Morrill et al., 2012b; Quigley et al., 2013). Although the correlation between Brix data and RID-determined IgG concentrations has been determined in previous studies (Chigerwe et al., 2008; Quigley et al., 2013), to the 
authors' knowledge no study has directly compared colostrum IgG concentrations determined by RID to both the colostrometer and Brix refractometer on individual cow samples. The objectives of this study were to determine whether the colostrometer or Brix refractometer is better able to determine colostrum quality compared with RID, and to determine the IgG content of colostrum on Alberta dairy farms.

\section{MATERIALS AND METHODS}

\section{Colostrum Sample Collection and Analysis}

Thirteen farms from central Alberta, Canada, participated in the study between February and July 2012. At each farm, the owner or an employee collected a 250-mL sample of first milking maternal colostrum (MC) before feeding the colostrum to the calf. Samples were labeled with cow identification number and date of collection and frozen at the farm at $-20^{\circ} \mathrm{C}$ until transported to the University of Calgary, where they were stored at $-80^{\circ} \mathrm{C}$. The $\mathrm{MC}$ samples were thawed at $4^{\circ} \mathrm{C}$ and then warmed to room temperature. When the samples were between 20 and $22^{\circ} \mathrm{C}$, they were analyzed for specific gravity using a colostrometer (JorVet Bovine Colostrometer, Jorgensen Laboratories, Loveland, CO) as described by Fleenor and Stott (1980). Briefly, samples were transferred to a clean and dry $100-\mathrm{mL}$ graduated cylinder. The colostrometer was gently floated in the sample until it came to rest and $\mathrm{IgG}$ concentration was measured at the meniscus. This was performed twice for each sample. Total solids were measured with a digital Brix refractometer (PAL-1, Atago Co. Ltd., Bellevue, WA) following the procedure of Bielmann et al. (2010). Briefly, 2 to 3 drops of colostrum were placed on the measurement prism and left for $1 \mathrm{~min}$ to allow for temperature adjustment before the reading was taken. For the RID analysis, the colostrum was warmed to $42^{\circ} \mathrm{C}$ to ensure homogeneity and an aliquot was frozen at $-80^{\circ} \mathrm{C}$. The $\operatorname{IgG}$ content was determined at Prairie Diagnostic Services (University of Saskatchewan, Saskatoon, SK, Canada) using rabbit anti-bovine IgG (heavy and light chains) as previously described (Chelack et al., 1993). The IgG values reported refer to the sum of all IgG isotypes. Animal care and ethics approvals were obtained from the Veterinary Science Animal Care Committee at the University of Calgary, and all procedures followed the guidelines of the Canadian Council on Animal Care (2009).

\section{Statistical Analysis}

In total, $569 \mathrm{MC}$ samples were collected. For the colostrometer analysis, 50 samples were outside of the measurement range of 0 to $140 \mathrm{mg} / \mathrm{mL}$ and were not included in the statistical analysis. The Brix refractometer had a range of 0 to $53 \%$ Brix and all 569 samples were within this range. The lower detection limit for RID analysis was $0.7 \mathrm{mg} / \mathrm{mL}$. The samples that were analyzed were all above this lower limit; however, not all samples collected were analyzed. This study was part of a larger study in which serum IgG levels in newborn calves were measured, and so only colostrum samples that were paired with a calf serum sample were analyzed; in total, 460 samples were analyzed for IgG by RID. Consequently, all statistical comparisons between RID, Brix refractometer, and colostrometer values were made using 460 samples.

Correlation analyses to compare RID with the Brix refractometer and colostrometer data were conducted using PROC CORR of SAS (version 9.3; SAS Institute Inc., Cary, NC). The data derived from the colostrometer were not normally distributed; several transformations were attempted to improve normality parameters but none improved the correlation with RID-measured IgG values. Because the data were non-normal, the Spearman correlation coefficient was used to compare colostrometer and RID data. The Spearman correlation coefficient was also used to compare the normally distributed Brix refractometer data and the RID data to allow for statistical comparison between the on-farm tools. Sensitivity and specificity (95\% CI) of the colostrometer and Brix refractometer were calculated using the RID data as the standard, with $50 \mathrm{mg} / \mathrm{mL}$ of $\mathrm{IgG}$ as the cut-point for adequate quality colostrum. Sensitivity measures the proportion of poor quality samples that are correctly identified as such, and specificity measures the proportion of adequate quality samples that are correctly identified as such. Six cut-points at intervals of $10 \mathrm{mg} / \mathrm{mL}$ from 50 to $100 \mathrm{mg} / \mathrm{mL}$ were considered for the colostrometer. For the Brix refractometer, 8 cut-points at 1-percentage-unit intervals from 18 to $25 \%$ Brix were considered. Sensitivity and specificity were summed, and the highest combined value was used to determine the appropriate cut-points for the colostrometer and Brix refractometer. This approach was used to minimize the risk of both false negatives and false positives (Windeyer et al., 2014). Positive and negative predictive values (95\% CI) were also calculated at each of the tested cut-points. The associations of RID data with the colostrometer and Brix refractometer data were analyzed while adjusting for covariates using the MIXED procedure of SAS. A multivariable model was tested that included parity and month of colostrum production as fixed effects and farm as a random effect, because previous literature suggests that colostrum quality may be influenced by month (Gulliksen et al., 2008) and parity (Morin et al., 
Table 1. Descriptive statistics for maternal colostrum samples collected from 13 farms in central Alberta and analyzed by radial immunodiffusion (RID), a Brix refractometer, and a colostrometer

\begin{tabular}{lcccc}
\hline Item & $\begin{array}{c}\text { No. of } \\
\text { samples }\end{array}$ & $\begin{array}{c}\text { Mean } \\
(95 \% \text { CI })\end{array}$ & Minimum & Maximum \\
\hline IgG by RID, $\mathrm{mg} / \mathrm{mL}$ & 460 & $63.7(61.5-65.9)$ & 8.3 & 128.6 \\
Brix, \% & 569 & $24.3(23.9-24.6)$ & 10.4 & 52.6 \\
IgG by colostrometer, $\mathrm{mg} / \mathrm{mL}$ & 519 & $82.3(79.8-84.8)$ & 0.0 & 140.0 \\
\hline
\end{tabular}

2001). The Brix and colostrometer data were compared to RID-measured IgG levels by PROC REG (SAS Institute Inc.).

\section{RESULTS}

For the RID-measured IgG, 134 out of 460 samples $(29.1 \%)$ were $<50 \mathrm{mg} / \mathrm{mL}$, whereas for the colostrometer, 73 out of 519 (14.1\%) samples were $<50 \mathrm{mg} / \mathrm{mL}$ (Table 1, Figure 1). Regarding the Brix refractometer data, 195 of the 569 samples $(34.3 \%)$ were below $23 \%$ Brix (Table 1, Figure 2), which is the cut-point recommended by Chigerwe et al. (2008). The correlation between RID-measured IgG concentrations and the Brix refractometer data was 0.64 (Figure 3), whereas the correlation between RID and colostrometer data was 0.77 (Figure 4).

The highest combined sensitivity and specificity for the detection of adequate quality colostrum, as determined by the gold standard of RID, occurred at $23 \%$ Brix (Table 2) and $80 \mathrm{mg} / \mathrm{mL}$ for the colostrometer (Table 3). At 23\%, the Brix had a sensitivity of $65.7 \%$ and specificity of $82.8 \%$. At $80 \mathrm{mg} / \mathrm{mL}$, the colostrometer had a sensitivity of $84.1 \%$ and a specificity of $77.0 \%$. At these cut-points, the Brix had an accuracy of $74.2 \%$, and the colostrometer had an accuracy of $80.1 \%$. Positive and negative predictive values indicate the probability that a test-positive or test-negative sample is truly of poor or adequate quality, respectively, given the prevalence in the sample population. At the above cut-points, if a sample tests lower than $80 \mathrm{mg} / \mathrm{mL}$ on the colostrometer, there is a $60.6 \%$ chance that it truly is poor quality $(<50 \mathrm{mg} / \mathrm{mL} \operatorname{IgG}$ as determined by RID) and, if it tests higher than $80 \mathrm{mg} / \mathrm{mL}$, a $92.0 \%$ chance that it is adequate quality. A sample testing lower than $23 \%$ Brix has a $61 \%$ chance of being truly inadequate, whereas a sample testing higher than $23 \%$ Brix has an $85.5 \%$ chance of being adequate, given the prevalence of poor and adequate quality colostrum in the sample population of this study.

Month of calving had no effect on colostral IgG content $(P=0.2)$. Parity affected colostral IgG concentration $(P<0.02)$, with third or higher parity cows having greater colostral $\mathrm{IgG}(69.5 \pm 1.98 \mathrm{mg} / \mathrm{mL})$ compared with second-parity $(59.8 \pm 2.06 \mathrm{mg} / \mathrm{mL})$ and first- parity cows $(62.2 \pm 1.73 \mathrm{mg} / \mathrm{mL})$. In the multivariable analyses, the farm variable, included as a random effect in the model, accounted for $8.14 \%$ of the total variation in colostrum quality. Using this model, the IgG values measured by colostrometer and Brix refractometer were each significantly associated with RID-measured IgG values. Each 1-percentage unit increase in percentage Brix equated to a RID-measured IgG increase of 3.0 $\mathrm{mg} / \mathrm{mL}$, and each $1 \mathrm{mg} / \mathrm{mL}$ increase in $\mathrm{IgG}$ measured by the colostrometer equated to a RID-measured IgG increase of $0.6 \mathrm{mg} / \mathrm{mL} \mathrm{IgG}$. In comparing the Brix refractometer- and colostrometer-measured IgG models, the colostrometer model had the higher goodness-of-fit based on the Akaike information criterion.

\section{DISCUSSION}

In the current study, the range of RID-measured colostrum IgG concentrations was smaller than the previously published ranges of 22.4 to $196.9 \mathrm{mg} / \mathrm{mL}$ (Bielmann et al., 2010), 1.8 to $200.2 \mathrm{mg} / \mathrm{mL}$ (Morrill et al., 2012a), and 7.1 to $159.0 \mathrm{mg} / \mathrm{mL}$ (Quigley et al., 2013). There are several possible explanations for the difference between the distribution of $\operatorname{IgG}$ concentration reported in the present study and previous

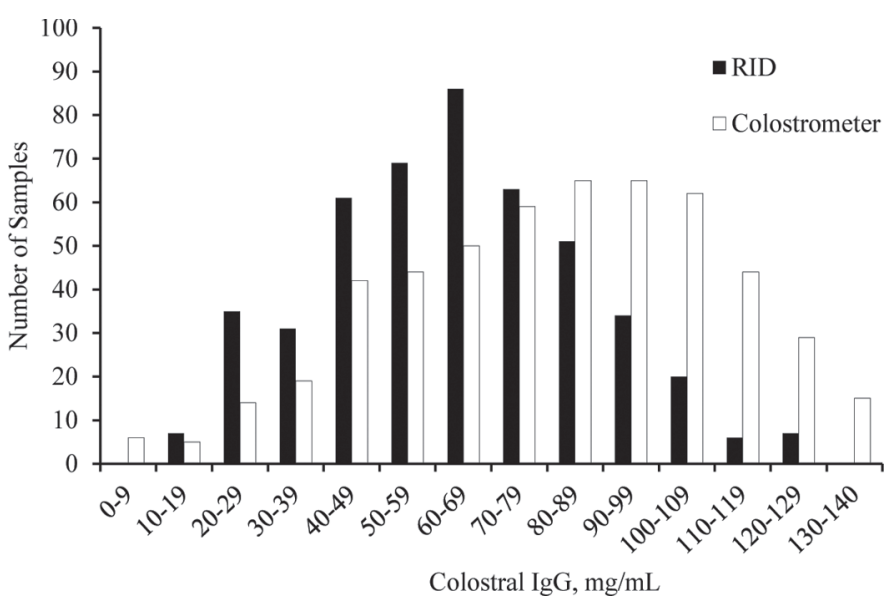

Figure 1. Distribution of radial immunodiffusion (RID) and colostrometer-determined IgG concentrations of maternal colostrum samples $(n=519$ colostrometer analysis, $n=460$ RID). Samples were collected from 13 farms around central Alberta, Canada. 


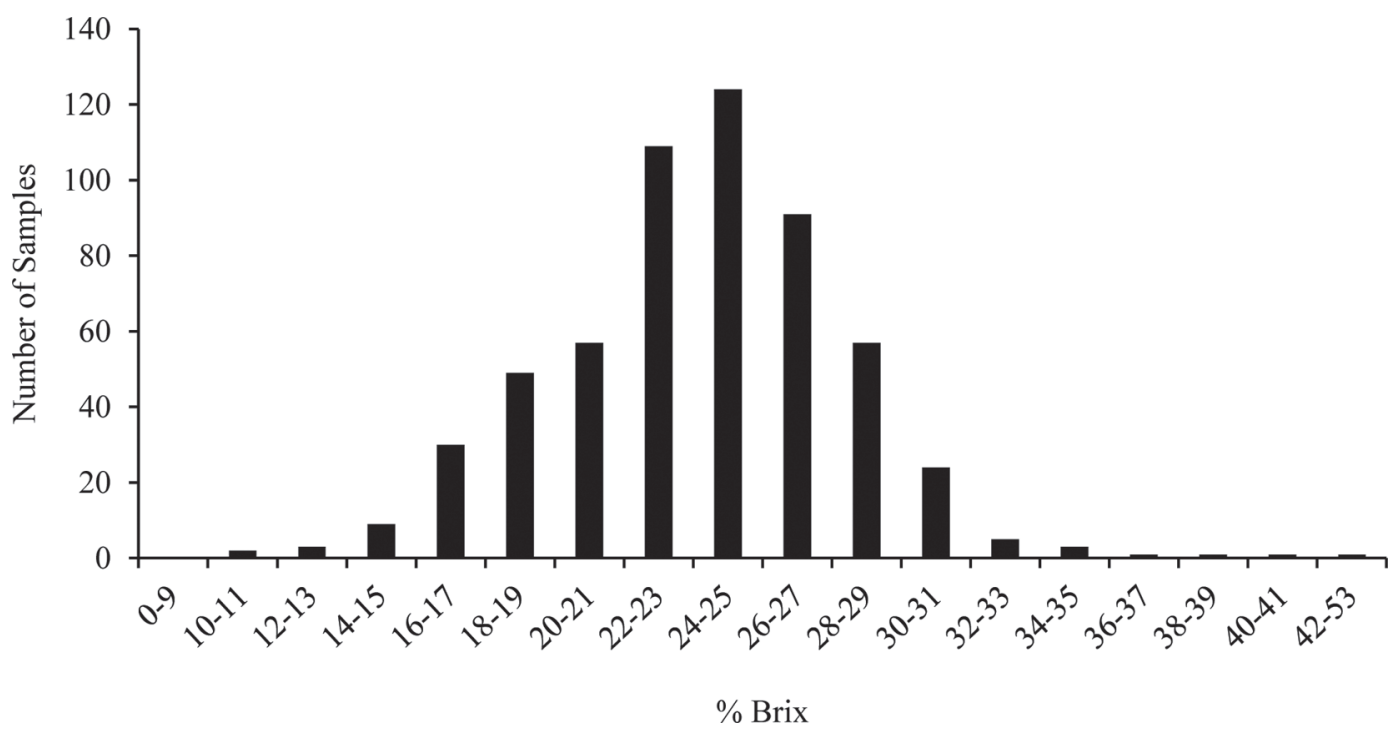

Figure 2. Distribution of colostrum samples analyzed with a digital Brix refractometer $(\mathrm{n}=569)$. Samples were collected from 13 farms around central Alberta, Canada.

studies. Thirteen commercial farms with herd sizes from 60 to 300 milking cows were used in the present study, whereas the Morrill et al. (2012a) study had 67 farms with herd sizes ranging from 70 to 5,000 milking cows. The larger number of farms likely represented a greater range of environmental conditions and management and nutritional practices that are known to affect colostrum quality (Godden, 2008). Variation in time to colostrum collection may also have affected the colostral IgG levels. Colostrum collected more than 2 $\mathrm{h}$ after parturition is significantly lower in IgG content than colostrum collected within a shorter period
(Hostetler et al., 2003; Moore et al., 2005; Chigerwe et al., 2008). In the current study, the producers collected the colostrum samples and time of collection relative to calving was not monitored. It is also possible that genetic variation contributed to the differences in IgG distribution, as previous studies in beef and dairy cows have suggested that colostral IgG concentration could be increased by genetic selection (Baumrucker et al., 2010).

The percentage of samples analyzed by RID containing $<50 \mathrm{mg} / \mathrm{mL}$ IgG was similar to the $32 \%$ reported by Chigerwe et al. (2008). Likewise, the colostrometer

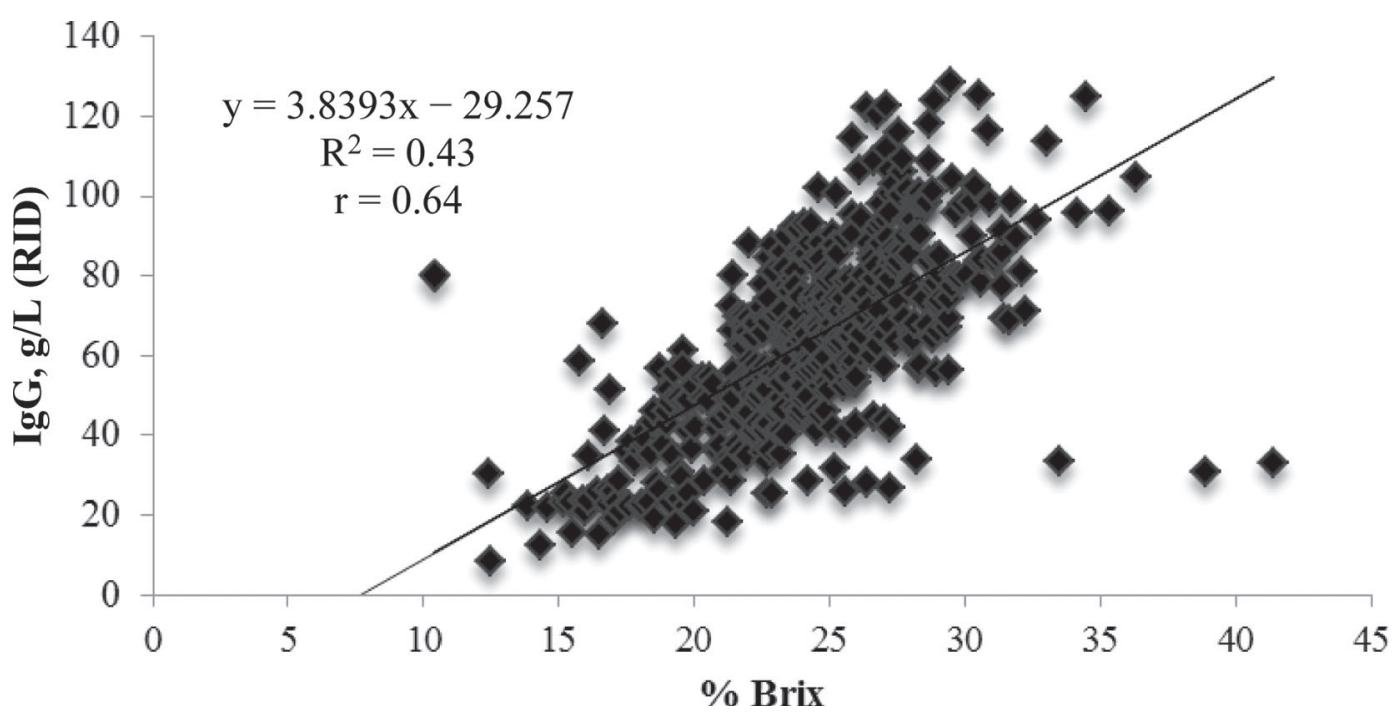

Figure 3. Scatter plot of percent Brix and radial immunodiffusion-measured IgG values $(\mathrm{n}=460)$. 
Table 2. Crude accuracy, sensitivity (Se), specificity (Sp), positive predictive value (PPV), and negative predictive value (NPV) for different Brix refractometer cut-points compared with $50 \mathrm{mg} / \mathrm{mL}$ IgG as measured by radial immunodiffusion ${ }^{1}$

\begin{tabular}{lcccccc}
\hline $\begin{array}{l}\text { Cut-point, } \\
\text { \% Brix }\end{array}$ & $\begin{array}{c}\text { Crude } \\
\text { accuracy, } \%\end{array}$ & Se, $\%$ & Sp, $\%$ & Se + Sp $^{2}$ & PPV, $\%$ & NPV, \% \\
\hline 18 & 75.8 & $22.4(14.7-29.4)$ & $98.1(96.6-99.6)$ & 1.21 & $82.4(65.5-93.2)$ & $75.3(70.9-79.4)$ \\
19 & 77.6 & $27.5(20.1-36.0)$ & $98.1(96.6-99.6)$ & 1.26 & $85.7(71.5-94.6)$ & $76.7(72.4-80.9)$ \\
20 & 80.5 & $40.5(32.0-49.4)$ & $96.9(94.3-98.5)$ & 1.37 & $84.1(72.7-92.1)$ & $79.9(75.6-83.8)$ \\
21 & 81.4 & $47.3(38.6-56.2)$ & $95.3(92.4-97.4)$ & 1.43 & $80.5(69.9-88.7)$ & $81.6(77.2-85.4)$ \\
22 & 80.9 & $54.2(45.3-62.9)$ & $91.9(88.3-94.6)$ & 1.46 & $73.2(63.2-81.7)$ & $83.1(78.7-86.8)$ \\
23 & 77.8 & $65.7(56.9-73.7)$ & $82.8(78.2-86.8)$ & 1.49 & $61.0(52.4-69.0)$ & $85.5(81.1-89.2)$ \\
24 & 73.2 & $74.8(66.5-82.0)$ & $72.5(67.3-77.3)$ & 1.47 & $52.7(45.3-60.0)$ & $87.6(83.0-91.3)$ \\
25 & 66.7 & $82.4(74.8-88.5)$ & $60.3(54.7-65.7)$ & 1.43 & $46.0(39.5-52.6)$ & $89.4(84.6-93.1)$ \\
\hline
\end{tabular}

${ }^{1} 95 \%$ confidence interval shown in parentheses for Se, Sp, PPV, and NPV.

${ }^{2}$ Sensitivity and specificity percentages converted into a unit value.

values are in agreement with Pritchett et al. (1994), who reported a mean of $82.1 \mathrm{mg} / \mathrm{mL} \operatorname{IgG}$, with $12 \%$ of the samples measuring $<50 \mathrm{mg} / \mathrm{mL}$. The mean Brix percentage was similar to previously reported means of $26.1 \%$ (Bielmann et al., 2010) and 23.8\% (Quigley et al., 2013). It is interesting to note that in the Quigley et al. (2013) study, the data were not normally distributed whereas in the current study they were; as a result, only $7 \%$ of the samples in the Quigley study measured $<20 \%$ Brix compared with $15.6 \%$ in the current study.

The correlation coefficient of 0.77 between the RIDmeasured IgG concentrations and the colostrometer data was approximately midway between the 0.63 reported by Quigley et al. (1994) for Jersey colostrum and the 0.87 reported by Mechor et al. (1992) for Holstein colostrum. The wide range of reported correlation coefficients could be due to variation in the content of non- $\operatorname{IgG}$ protein in the colostrum because specific gravity is better correlated with total colostral protein than IgG itself (Morin et al., 2001). The correlation coefficient between the RID data and Brix refractometer $(r=0.64)$ was identical to that reported by Chigerwe et al. (2008) but lower than the correlation coefficients of 0.71 to 0.75 reported by other groups (Bielmann et al., 2010; Morrill et al., 2012b; Quigley et al., 2013). Because the Brix refractometer measures total dissolved solids and not IgG specifically, differences in the nutrient content of the colostrum in these studies may have contributed to the variation in the correlation coefficients. Dry period length (Rastani et al., 2005), vaccination status of the dam (Hodgins and Shewen, 1996), and season of parturition (Morin et al., 2001) have also been shown to have an effect on the concentration of dissolved components.

The $\mathrm{R}^{2}$ for Brix versus RID-measured IgG in the current study $(0.43$, Figure 3$)$ is comparable to the 0.41 of

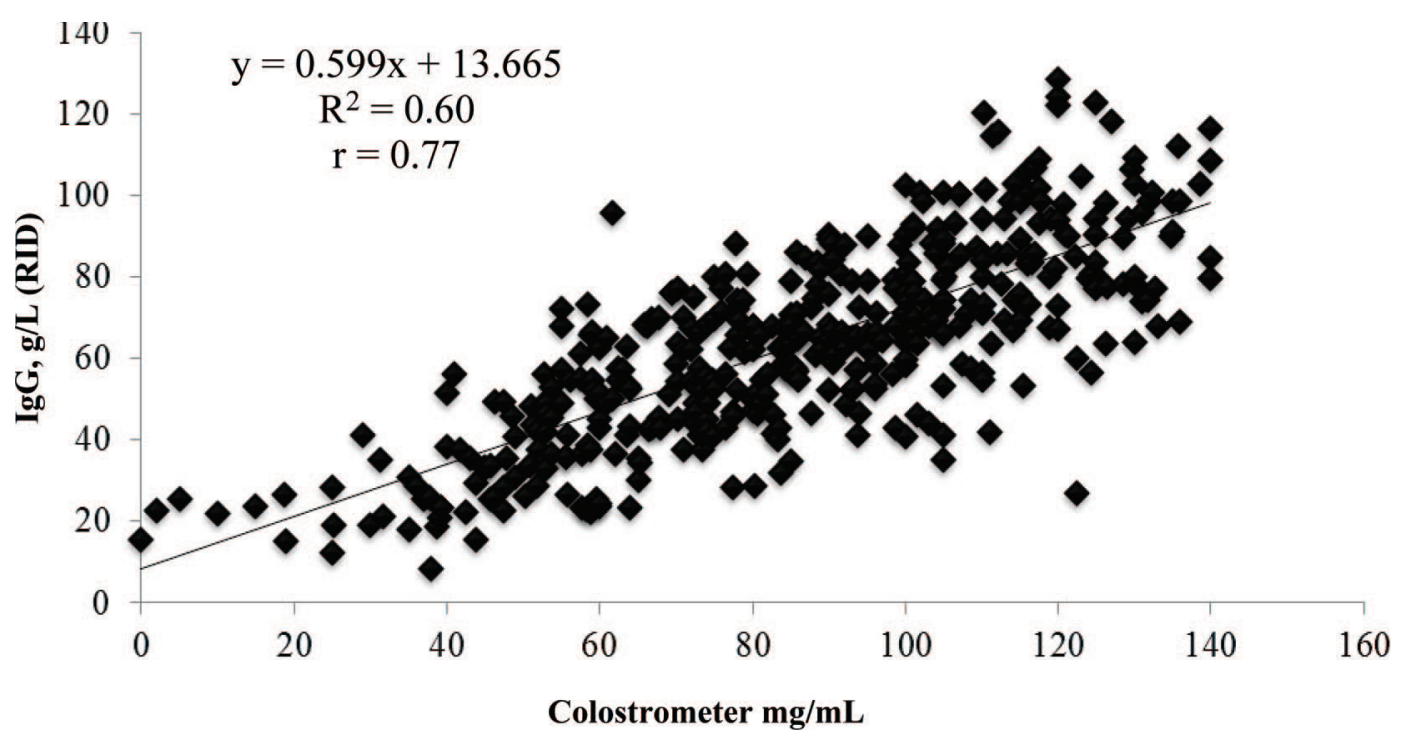

Figure 4. Scatter plot of the colostrometer and radial immunodiffusion (RID)-determined IgG levels $(\mathrm{n}=460)$. 
Table 3. Crude accuracy, sensitivity (Se), specificity (Sp), positive predictive value (PPV), and negative predictive value (NPV) for different colostrometer cut-points compared with $50 \mathrm{mg} / \mathrm{mL}$ IgG as measured by radial immunodiffusion ${ }^{1}$

\begin{tabular}{lcccccc}
\hline $\begin{array}{l}\text { Cut-point, } \\
\mathrm{mg} / \mathrm{mL}\end{array}$ & $\begin{array}{c}\text { Crude } \\
\text { accuracy, } \%\end{array}$ & $\mathrm{Se}, \%$ & $\mathrm{Sp}, \%$ & $\mathrm{Se}+\mathrm{Sp}^{2}$ & $\mathrm{PPV}, \%$ & $\mathrm{NPV}, \%$ \\
\hline 50 & 81.8 & $41.3(32.2-50.0)$ & $98.3(96.6-99.6)$ & 1.40 & $91.2(82.7-98.0)$ & $80.0(75.1-83.6)$ \\
60 & 84.5 & $61.1(51.6-69.2)$ & $94.0(91.0-96.6)$ & 1.55 & $81.1(72.6-89.1)$ & $85.2(80.5-88.5)$ \\
70 & 83.1 & $70.6(61.3-77.9)$ & $88.0(84.0-91.7)$ & 1.59 & $71.2(63.0-79.5)$ & $87.7(83.0-90.9)$ \\
80 & 78.7 & $84.1(76.7-90.1)$ & $77.0(69.6-84.4)$ & 1.61 & $60.6(53.2-68.1)$ & $92.0(87.8-95.0)$ \\
90 & 71.2 & $92.8(87.0-98.7)$ & $62.0(53.2-68.1)$ & 1.55 & $50.7(44.7-58.0)$ & $95.4(91.4-97.9)$ \\
100 & 63.0 & $96.0(91.1-98.7)$ & $49.3(44.7-56.3)$ & 1.45 & $44.3(38.8-51.0)$ & $96.7(92.5-98.9)$ \\
\hline
\end{tabular}

${ }^{1} 95 \%$ confidence interval shown in parentheses for Se, Sp, PPV, and NPV.

${ }^{2}$ Sensitivity and specificity percentages converted into a unit value.

Chigerwe et al. (2008) but lower than the 0.53 reported by Bielmann et al. (2010) and the 0.56 of Quigley et al. (2013). For the colostrometer versus RID-measured IgG values, Chigerwe et al. (2008) reported an $\mathrm{R}^{2}$ of 0.41, and Pritchett et al. (1994) reported an $\mathrm{R}^{2}$ of 0.47 , both of which are lower than the $\mathrm{R}^{2}$ in the current study (0.60). Possible contributors to the difference in $\mathrm{R}^{2}$ for colostrometer versus RID-measured IgG values found in this and previous studies include variation in non-IgG colostral protein, colostrum collection and handling procedures, cow management, and season of parturition.

Although the results indicate that the colostrometer was more highly correlated with actual IgG levels, the colostrometer is not used frequently on farms. Vasseur et al. (2010) stated that even though producers are aware of the benefits of using a colostrometer utilization remains low, possibly due to its fragility and inconvenience of use. The digital Brix refractometer provides a user-friendly alternative to the colostrometer. Furthermore, this tool can be used for measuring other parameters on farm, including FTP (Deelen et al., 2014) and total solids in milk (Chigerwe and Hagey, 2014).

Previous studies have suggested that the appropriate cut-point for good quality colostrum measured by the Brix refractometer is between 20 and $23 \%$ (Chigerwe et al., 2008; Bielmann et al., 2010; Quigley et al., 2013). It is in the best interest of the calf to use the highest reasonable cut-point to ensure that adequate quality colostrum is correctly identified as such, while balancing the need to ensure adequate colostrum is not discarded in error; therefore, $23 \%$ is the most appropriate cut-point as supported by the findings of the present study. With regard to the cut-point for the colostrometer, our data indicate a value of $80 \mathrm{mg} / \mathrm{mL}$ is appropriate. Chigerwe et al. (2008) recommended using a range of 60 to 90 $\mathrm{mg} / \mathrm{mL}$ to reduce misclassification of false negatives.

Colostrum from third-parity cows had the highest IgG concentrations compared with colostrum from first- and second-parity cows, in agreement with previous reports (Muller and Ellinger, 1981; Tyler et al., 1999; Bielmann et al., 2010). This parity effect may be the result of older cows having had more exposure to antigens compared with younger cows, leading to higher IgG content in their colostrum. Although all colostrum should be tested for IgG content before feeding it, this is especially important for first- and second-parity cows because it is more likely that colostrum from these cows will contain $<50 \mathrm{mg} / \mathrm{mL} \mathrm{IgG}$.

\section{CONCLUSIONS}

The amount of IgG that the calf consumes is one of the most important factors influencing successful transfer of passive immunity; therefore, it is essential to have an on-farm tool available for producers to measure colostrum quality. The Brix refractometer is a suitable tool because it is user-friendly and functions independently of colostrum temperature. This study demonstrates that $23 \%$ Brix should be used as the cutpoint for adequate quality colostrum. The colostrometer overestimates $\operatorname{IgG}$ content but is still a good tool to use on farm, provided that a cut-point of $80 \mathrm{mg} / \mathrm{mL}$ is used.

\section{REFERENCES}

Baumrucker, C. R., A. M. Burkett, A. L. Magliaro-Macrina, and C. D. Dechow. 2010. Colostrogenesis: Mass transfer of immunoglobulin $\mathrm{G}_{1}$ into colostrum. J. Dairy Sci. 93:3031-3038.

Beam, A. L., J. E. Lombard, C. A. Kopral, L. P. Garber, A. L. Winter, J. A. Hicks, and J. L. Schlater. 2009. Prevalence of failure of passive transfer of immunity in newborn heifer calves and associated management practices on US dairy operations. J. Dairy Sci. 92:3973-3980.

Bielmann, V., J. Gillan, N. R. Perkins, A. L. Skidmore, S. Godden, and K. E. Leslie. 2010. An evaluation of Brix refractometry instruments for measurement of colostrum quality in dairy cattle. J. Dairy Sci. 93:3713-3721.

Calloway, C. D., J. W. Tyler, R. K. Tessman, D. Hostetler, and J. Holle. 2002. Comparison of refractometers and test endpoints in the measurement of serum transfer status in calves. J. Am. Vet. Med. Assoc. 221:1605-1608. 
Canadian Council on Animal Care. 2009. The care and use of farm animals in research, teaching and testing. CCAC, Ottawa, ON, Canada.

Chigerwe, M., and J. V. Hagey. 2014. Refractometer assessment of colostral and serum IgG and milk total solids concentrations in dairy cattle. BMC Vet Res. 10:178.

Chigerwe, M., J. W. Tyler, J. R. Middleton, J. N. Spain, and J. S. Dill. 2008. Comparison of four methods to assess colostral IgG concentration in dairy cows. J. Am. Vet. Med. Assoc. 233:761-766.

Deelen, S. M., T. L. Ollivett, D. M. Haines, and K. E. Leslie. 2014. Evaluation of a Brix refractometer to estimate serum immunoglobulin G concentration in neonatal dairy calves. J. Dairy Sci. 97:3838-3844.

Fleenor, W. A., and G. H. Stott. 1980. Hydrometer test for estimation of immunoglobulin concentration in bovine colostrum. J. Dairy Sci. 63:973-977.

Godden, S. 2008. Colostrum management for dairy calves. Vet. Clin. North Am. Food Anim. Pract. 24:19-39.

Gulliksen, S. M., K. I. Lie, L. Sølverød, and O. Østerås. 2008. Risk factors associated with colostrum quality in Norwegian dairy cows. J. Dairy Sci. 91:704-712.

Hodgins, D. C., and P. E. Shewen. 1996. Preparturient vaccination to enhance passive immunity to the capsular polysaccharide of Pasteurella haemolytica A1. Vet. Immunol. Immunopathol. 50:67-77.

Hostetler, D., V. L. Douglas, J. Tyler, J. Holle, and B. Steevens. 2003 Immunoglobulin $\mathrm{G}$ concentrations in temporal fractions of first milking colostrum in dairy cows. Int. J. Appl. Res. Vet. Med. 1:168-171.

Larson, B. L., H. L. Heary, and J. E. Devery. 1980. Immunoglobulin production and transport by the mammary gland. J. Dairy Sci. 63:665-671.

Margerison, J., and N. Downey. 2005. Guidelines for optimal dairy heifer rearing and herd performance. Pages 307-338 in Calf and Heifer Rearing - Principles of Rearing the Modern Dairy Heifer. P. C. Garnsworthy, ed. Nottingham University Press, London, UK.

McGuirk, S. M., and M. Collins. 2004. Managing the production, storage, and delivery of colostrum. Vet. Clin. North Am. Food Anim. Pract. 20:593-603.

Mechor, G. D., Y. T. Gröhn, L. R. McDowell, and R. J. Van Saun. 1992. Specific gravity of bovine colostrum immunoglobulins as affected by temperature and colostrum components. J. Dairy Sci. 75:3131-3135.

Moore, M., M. Chigerwe, M. E. Dawes, J. W. Tyler, and J. R. Middleton. 2005. Effect of delayed colostrum collection on colostral IgG concentration in dairy cows. J. Am. Vet. Med. Assoc. 226:13751377.

Morin, D. E., P. D. Constable, P. Maunsell, and G. C. McCoy. 2001. Factors associated with colostral specific gravity in dairy cows. J. Dairy Sci. 84:937-943.

Morrill, K. M., E. Conrad, A. Lago, J. Campbell, J. Quigley, and H. Tyler. 2012a. Nationwide evaluation of quality and composition of colostrum on dairy farms in the United States. J. Dairy Sci 95:3997-4005.

Morrill, K. M., J. D. Quigley, A. Lago, and H. D. Tyler. 2012b. Estimate of colostral IgG concentration using refractometry without or with caprylic acid fractionation. J. Dairy Sci. 95:3987-3996.

Muller, L. D., and D. K. Ellinger. 1981. Colostral immunoglobulin concentrations among breeds of dairy cattle. J. Dairy Sci. 64:17271730.

Pritchett, L. C., C. C. Gay, D. D. Hancock, and T. E. Besser. 1994. Evaluation of the hydrometer for testing immunoglobulin G1 concentrations in Holstein colostrum. J. Dairy Sci. 77:1761-1767.

Quigley, J. D., A. Lago, C. Chapman, P. Erickson, and J. Polo. 2013 Evaluation of the Brix refractometer to estimate immunoglobulin G concentration in bovine colostrum. J. Dairy Sci. 96:1148-1155.

Quigley, J. D., K. R. Martin, H. H. Dowlen, L. B. Wallis, and K. Lamar. 1994. Immunoglobulin concentration, specific gravity, and nitrogen fractions of colostrum from Jersey cattle. J. Dairy Sci. $77: 264-269$

Rastani, R. R., R. R. Grummer, S. J. Bertics, A. Gumen, M. C. Wiltbank, D. G. Mashek, and M. C. Schwab. 2005. Reducing dry period length to simplify feeding of transition cows: Milk production, energy balance, and metabolic profiles. J. Dairy Sci. 88:1004-1014.

Tyler, J. W., B. J. Steevens, D. E. Hostetler, J. M. Holle, and J. L. Denbigh. 1999. Colostral IgG concentrations in Holstein and Guernsey cows. Am. J. Vet. Res. 60:1136-1139.

Vasseur, E., F. Borderas, R. I. Cue, D. Lefebvre, D. Pellerin, J. Rushen, K. M. Wade, and A. M. de Passillé. 2010. A survey of dairy calf management practices in Canada that affect animal welfare. J. Dairy Sci. 93:1307-1315.

Windeyer, M. C., K. E. Leslie, S. M. Godden, D. C. Hodgins, K. D. Lissemore, and S. J. LeBlanc. 2014. Factors associated with morbidity, mortality, and growth of dairy heifer calves up to 3 months of age. Prev. Vet. Med. 113:231-240. 